\title{
Research of the Biotope Diversity for the Purposes of Economic Valuation of Ecosystem Services in Chepelare Municipality (The Rhodopes Region of Bulgaria)
}

\author{
A. Assenov ${ }^{1}$, K. Vassilev ${ }^{2}$, H. Padeshenko, B. Koulov ${ }^{3}$, E.Ivanova ${ }^{4}$, B. Borisova ${ }^{1}$
}

\begin{abstract}
.
The application of the philosophy or the management model for sustainable development has two main shortcomings - the condition of the global environment gets worse and the social inequalities deepen. Regardless of the integrity of UN Sustainable Development Goals 2030, the manifestation of the effect of the false demarcation between ecology and development continues. The integrated philosophy for sustainability and development is enriched with new terms, such as natural capital and ecosystem goods and services, while their assessment and evaluation is crucial for the achievement of sustainable development.

The habitat, biotope and landscape diversity interpreted in GIS environment through evaluation of ecosystem goods and services in Chepelare Municipality is the main aim of the research, illustrated with maps of the biotopes, habitat types and landscapes. The obtained data through a GIS-based approach for evaluation and assessment of the ecosystem services is of high importance for the wellbeing of the municipality's population. The results about the economic value of two main ecosystem services - wild fruits and herbs and genetic resources are comparable with results from other similar studies. An attempt is made for harmonization of information from different scales for examination - land cover classes with habitat types, biotopes and landscapes aiming at the precise evaluation of the interpreted ecosystem goods and services.
\end{abstract}

Keywords: Biodiversity, biotope, habitat type, landscape biodiversity, environmental management, GIS.

\section{Thesis statement}

In 2015, the UN General Assembly adopted the Programme for sustainable development by 2030, with 17 new set of global objectives. Regardless of the institutionalizing of the sustainable development concept, its practical application shows two major drawbacks. First, the condition of the environment continues to deteriorate and secondly - social inequality worldwide is deepening. A composite part of the philosophy integrating sustainability and development is the concept of biodiversity, which after Rio de Janeiro (1992) has become the foundation of the environmental pillar of sustainable development. Upgrading terminological creativity in the philosophy of sustainable development, or rather in parallel with it, caused the penetration of the

| ${ }^{1}$ Department of Landscape Ecology and Environmental Protection, Faculty of Geology and Geography, Sofia University "St.Kliment Ohridski".

${ }^{2}$ Department of Plant and Fungal Diversity and Resources of the Institute of Biodiversity and Ecosystem Research at the Bulgarian Academy of Sciences.

${ }^{3}$ National Institute of Geophysics, Geodesy, and Geography at the Bulgarian Academy of Sciences.

${ }^{4}$ Department of Aerospace Information at Space Research and Technology Institute, Bulgarian Academy of Science, Sofia. 
concept of natural capital in a wider scientific interpretation. Chapter 3 of the synthesis report on "The European Environment - state and outlook 2015" of the European Environment Agency (EEA, 2015), entitled "Protecting, conserving and enhancing NC" states that "Natural capital is the most fundamental of the core forms of capital (i.e. manufactured, human, social and natural) since it provides the basic conditions for human existence. These conditions include fertile soil, multifunctional forests, productive land and seas, good quality freshwater and clean air. They also include services such as pollination, climate regulation and protection from natural disasters (EU, 2013). Natural capital sets the ecological limits for our socio-economic systems; it is both limited and vulnerable". The same report determines that the implementation of the concept of nature as capital raises certain difficulties. These include problems associated with the increasing transformation of the world into a commodity and the lack of understanding of the inherent importance of biodiversity and of a clean, healthy environment. In this context, it is important to emphasize that natural capital does not coincide with nature. Natural capital is the basis for the production of human economy and a provider of ecosystem services. Therefore, any socio-economic valuation of the European natural capital as an important tool for the integration of monetary values in economic systems and related policies should go hand in hand with the understanding that the economic assessment will not include the full intrinsic value of nature or cultural and spiritual services that it provides.

\section{Aim and Methodology}

The EU Biodiversity Strategy calls on Member States to map and assess the state of ecosystems and their services nationwide starting in 2014, with the support of the European Commission. Also, the economic value of these services has to be assessed and the integration of these values into accounting and reporting systems at EU and national level by 2020 needs to be promoted. Currently, projects for biophysical assessment of ecosystem goods and services are in process of realization, and then projects for monetary valuation are envisaged. World Bank (Vincent, 2012) reports that there is no movement towards valuation of natural capital and the problem still is considered at the conceptual level. Valuation of ecosystem goods and services, except at EU and national level in the Member States, is particularly important at the municipal level as a tool for implementation of a program for sustainable development in the respective municipality.

The main objective of this study is to carry out a valuation of potential genetic biodiversity in the form of herbs, berries and mushrooms of the municipality of Chepelare in the Rhodope Mountains (Bulgaria) on the ground of existing biotopes, habitat diversity and landscape biodiversity in GIS environment.

The research team utilized existing data from the forest management plans of "Chepelare" and "Hvoina" State Forestries, located within the territory of Chepelare Municipality. Data from the Municipal Development Plan of the municipality for the period $2014-2020$ is also used. Information about the declared amounts of herbs and mushrooms collected annually within the municipality of Chepelare is considered and analyzed. Independent field studies were carried out by the research team in terms of 
biotopes, habitat types and landscapes in the area of the municipality. Monetary evaluation of ecosystem/landscape goods was done through a conducted questionnaire survey among local population, based on the contingent valuation method, combined with the method of market prices.

For the purpose of the study landscape classification was developed based on a system of representative criteria for their structure, functions and dynamics, and in compliance with current European decisions on systematization of contemporary landscapes (Mücher et al., 2010). Visualization of identified landscape units was conducted in an environment of ArcGIS 10.3. (Fig. 1). On this information basis, analysis of spatial landscape structure was made using FRAGSTATS (McGarigal, et al., 2012). In parallel, the research team conducted economic valuation of a selection of representative provisioning and cultural ecosystem services within the classes of land cover (CLC 2012) in the boundaries of the municipality. Currents studies are a phase of the systematic research conducted by the team in the Rhodopes aimed at supporting the sustainable development of mountain communities.

\section{Study Area}

The study area is one of the 10 municipalities in Smolyan administrative region as part of the South Central Planning Region and covers a territory of $375 \mathrm{~km}^{2}$. According to data of National Statistical Institute (NSI) as of 31.12.2012 the municipality has a population of 7494 inhabitants, of which 5254 live in the administrative center - the town of Chepelare, which means that $70 \%$ of the total population lives in the municipal center, and the remaining 30\% are distributed in villages. According to various naturegeographical regionalization of Bulgaria the municipality always falls in the Western Rhodopes, and is featured by well-expressed mountainous relief. The altitude of Chepelare Municipality ranges from $2091 \mathrm{~m}$ at Golyam Persenk peak to $620 \mathrm{~m}$ at the exit of Chepelarska River from the area of the municipality. Chepelare Municipality is located along the Chepelarska River valley having a north-south orientation. In terms of climate the municipality falls in the Western Rhodopes region of transitional climatic conditions (Velev, 2010). The climatic characteristics of Western Rhodopes climatic region (Table 1), presented by average indicators, provide a general idea of climate, although not fully accurate for the actual space occupied by the municipality of Chepelare, because "the notion that the term "climate" has an abstract nature creates uncertainty for the entire conceptual apparatus and the spatial scope of interrelations with the lithosphere, hydrosphere and biosphere globally, which is a precondition for even greater uncertainty in clarifying the climatic peculiarities of small areas" (Toplyiski, 1998).

Table 1. Climatic characteristics of Western Rhodopes climatic region (after Velev, 2010)

\begin{tabular}{|l|l|}
\hline Average annual temperature in ${ }^{\circ} \mathrm{C}$ & 7,5 \\
\hline Temperature amount for the period of $\mathrm{t}>10^{\circ} \mathrm{C}$ & 1900 \\
\hline Duration of period without frost (in days) & 160 \\
\hline Annual temperature amplitude in ${ }^{\circ} \mathrm{C}$ & 19,3 \\
\hline
\end{tabular}




\begin{tabular}{|l|l|}
\hline Average annual wind speed in $\mathrm{m} / \mathrm{s}$ & 1,8 \\
\hline Number of days with wind speed over $14 \mathrm{~m} / \mathrm{s}$ & 35 \\
\hline Annual rainfall in $\mathrm{mm}$ & 850 \\
\hline Annual number of days with snow cover & 100 \\
\hline Annual number of days with fog & 35 \\
\hline Annual number of cloudy days in general cloudiness & 110 \\
\hline Years. number of clear days in general cloudiness & 70 \\
\hline
\end{tabular}

In Chepelare Municipality $73 \%$ of the territory is covered by forests, $14 \%$ - by pastures, $11 \%$ is arable land and $2 \%$ are settlements. The species involved in the composition of forests are distributed as follows: Pinus sylvestris - 21.35\%, Picea abies - 49.65\%, Pinus nigra, Abies alba and other coniferous species - 14.6\%, Fagus sylvatica - 5.85\%, Quercus dalechampii - 4.45\% and other deciduous species - 3.75\%. There are internal differences in the spatial distribution of the different species - for example, Picea abies occupies twice more space in the southern part compared to the north, Pinus nigra, Abies alba and other coniferous species in this category occupy only one percent in the north, while the remaining $28.4 \%$ are spread in the southern part of the municipality, Quercus dalechampii has three times larger territories in the north, and the other deciduous species are also more than 10 times larger in coverage in the north, around the village of Hvoina, which is conditioned by the lower altitude of relief. Occupied space by Fagus sylvatica in the north is more than two times greater than that in the southern part.

Chepelare Municipality includes parts of the following protected areas of NATURA 2000 ecological network under the Biological Diversity Act: BG0001030 "Rodopi Zapadni" and BG0001031 "Rodopi - Sredni" for the preservation of natural habitats and of wild flora and fauna; and BG0002105 "Persenk" for the preservation of wild birds, whose territory coincides with the Important Bird Area (IBA) "Persenk" with code BG105. The following protected areas under the Protected Areas Act (PAA) fall within the municipality of Chepelare: the protected localities "Srednite livadi" and "Kutsinsko blato", and the natural landmarks "Wonderful Bridges - Erkyupria", "Skakaloto", "Duplevo" and "Kosten kamak".

The landscape differentiation carried out shows that the variety of landscape units in Chepelare Municipality is 39\% (RPR) from the possible maximum according to the selected criteria of differentiation (262 units - PR). The relatively high value is a good indicator, reflecting the age of the landscapes in the Rhodope Mountains and the dynamics of their development. The landscape structure of the municipality is favorable and is dominated by the representative for the Rhodopes landscapes of coniferous forests and pastures in the alpine zone. 


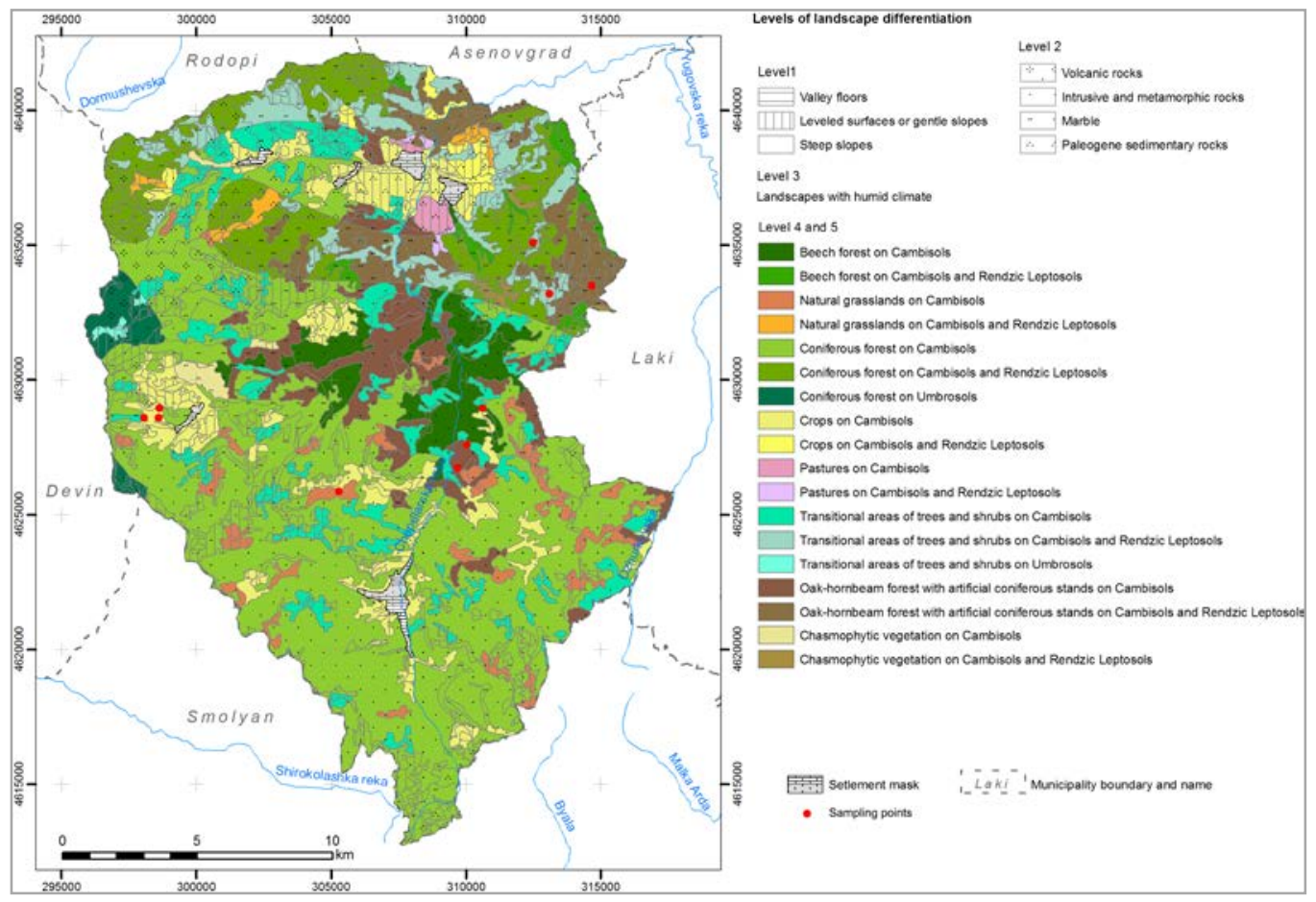

Fig. 1. Landscape map of Chepelare Municipality (Borissova and Assenov, 2016)

The variation in the values of the Landscape Shape Index of Chepelare Municipality is alarming and clearly speaks for enhanced systems dynamics and evidence of transformation processes. On the landscape map they could clearly be traced in the spatial organization of landscapes of the transitional tree and shrub vegetation in the midst of natural landscapes of coniferous forests. In our opinion the main negative factor in this regard is the nature of land use, which is traditionally dispersed in separate independent areas of mountain pastures, meadows and small areas of arable land (Fig. 1).

\section{Results}

The flora of the municipality of Chepelare is a combination of all plant species distributed in the geographic area of the municipality arranged hierarchically and phylogenetically in taxonomic categories, including representatives of antropophytes incurred accidentally or intentionally in nature. From the perspective of biodiversity, flora is part of taxonomic diversity of Bulgaria known mostly as species diversity. According to the "Conspectus of the Bulgarian Vascular Flora" (Assyov et al., 2012) 4102 species of higher plants, together with the representatives of antropophytes, are distributed in Bulgaria. Based on literature and own numerous field studies in Chepelare Municipality the research team determined that the floristic taxonomic biodiversity of higher plants includes about 2100 species or $52 \%$ of floristic diversity of Bulgaria.

In the Rhodopes 364 species of briophytes are described, of which 75 species of 
liverworts and 289 of moss species (Ganeva, 2006). Approximately 51\% of moss species distributed in Bulgaria are found in the Rhodopes. Although the exact moss species diversity of the municipality cannot be specified it can be assumed that due to the relatively well-preserved natural environment in the area at least half of all species described so far in the Rhodopes are found here.

In the Rhodope Mountains 1616 species of algae have been studied (Temniskova and Kirjakov, 2006), of which 826 are found in lakes, 41 in warm mineral waters, 85 in dams, 12 in channels and 76 in fishponds or 923 species described as habitats should not be present in the research area because of the lack of lakes, dams and channels. If we subtract these species (923 species) of the total number of species in the Western Rhodopes (1616 species) we can conclude that in Chepelare Municipality approximately 693 species of algae are distributed, which represents approximately $23 \%$ of the algae in Bulgaria (3063 species algae - Temniskova et al., 2005), but perhaps this figure is too low. Specific part of taxonomic biodiversity of our country is the fungal biodiversity, which according to the studied fungi includes 5200 species and their number may reach for the country 20670 species (Denchev et al., 2005). Fungi are closer to animal than to plant kingdom and, according to the cited authors, after sufficient volume of published material should be classified in a single system. Authors studied fungal diversity of the Rhodopes (Denchev et al., 2006) state that 1763 species of fungi have been identified. A distinction in their fields is made according to the botany-geographic regions of Bulgaria (Assyov et al., 2001, 2002, 2006, 2012) between species common in the Western, Central and Eastern Rhodopes. The total number of fungi prevalent in the Western Rhodopes, according to the above-mentioned authors, is 925 species, which figure does not include 484 lichenized and non-lichenized fungi, because they lack the exact distribution of deposits in Western, Central and Eastern Rhodope Mountains. Listed 925 species of fungi in Western Rhodopes (609 species published by the respective authors and 316 species not published in scientific literature) represent $18.88 \%$ of the total fungal diversity in Bulgaria. The identified 925 fungi species in Western Rhodopes are distributed as follows: 15 species of Oomycetes, 107 species of non-lichenized Ascomycetes, 65 species of anamorphic fungi and 422 species of Basidiomycetes. Given the alleged volume of 20670 fungi species in our country (Denchev al., 2005), fungal diversity of Chepelare Municipality can reach much higher values.

The functioning of biodiversity and ecosystem services in the form of genetic resources such as berries, medicinal plants and herbs is presented according to habitat diversity and available classes of EUNIS classification in Chepelare Municipality. In other European countries such as the Scandinavian countries with classical historical development in the study of biodiversity, its functional nature is presented in the form of biotopes. In Finland, similar research has been done (Vihervaara et al., 2012) using the existing national classifications of biotopes. According to the same study in the classification of biotopes, the term biotope is used as a synonym for habitat and means "territory or aquatory with appropriate environmental conditions for the development of flora and fauna, and the structure of communities they form". In a previous study (Vihervaara et al., 2010), the land cover classes are interpreted and it is found that information on biodiversity is much more accurate for existing biotope classifications in Finland. At the same time, it is recognized that Eurostat information system with its EUNIS 
classification (Davies and Moss, 1997; Davies et al., 2004), as types of EUNIS habitat is a comprehensive pan-European classification system and facilitates harmonization of the system for description and data collection throughout Europe, using criteria for identification of habitats. It covers all types of habitats, natural and artificial, from land to freshwater and marine, and EUNIS data is collected and maintained by the European Topic Centre on Biological Diversity at the European Environment Agency. Bulgaria lacks a unified Bulgarian classification system of biotopes, but above-mentioned findings on the role of habitat types in EUNIS suggests that their pan-European nature eliminates the need for biotope classification, especially for the needs of this particular study.

On the map of habitat diversity (Fig. 2) in the municipality of Chepelare the basic codes of the EUNIS classification are presented while all habitat types (28 types) in the municipality are indicated in Table 2 . The table data show that 8 habitat types have area below 10 hectares, and only habitat types 9410 and 91CA have significant weight, respectively $8471.2 \mathrm{ba}$ and $3394.2 \mathrm{ba}$ (Table 2), which in percent is very close to the values of the areas occupied by Picea abies and Pinus sylvestris appointed in the Municipal Development Plan of Chepelare (2014-2020). During the terrain research10 points are described in habitat types 4060, 5130, 6110, 6520, 9110 (2 points), 91CA, 9410 (2 points) and 9530 (Fig. 2).

Table 2. Habitat types and area (ha) in Chepelare Municipality

\begin{tabular}{|c|c|c|}
\hline Code and name after Directive 92/43 EEC & $\begin{array}{l}\text { Code and name after EUNIS } \\
\text { classification }\end{array}$ & Area (ha) \\
\hline 4060 Alpine and Boreal heaths & $\begin{array}{l}\text { F2. Arctic, alpine and subalpine } \\
\text { scrub }\end{array}$ & 37,5 \\
\hline $\begin{array}{l}5130 \text { Juniperus communis formations on heaths or } \\
\text { calcareous grasslands }\end{array}$ & $\begin{array}{l}\text { F3. Temperate and } \\
\text { Mediterranean-montane scrub }\end{array}$ & 195,0 \\
\hline $\begin{array}{l}\text { 6110* Rupicolous calcareous or basophilic } \\
\text { grasslands of the Alysso-Sedion albi }\end{array}$ & $\begin{array}{l}\text { F3. Temperate and } \\
\text { Mediterranean-montane scrub }\end{array}$ & 9,5 \\
\hline 6170 Alpine and subalpine calcareous grasslands & $\begin{array}{l}\text { E4. Alpine and subalpine } \\
\text { grasslands }\end{array}$ & 50,8 \\
\hline $\begin{array}{l}6210 \text { Semi-natural dry grasslands and scrubland } \\
\text { facies on calcareous substrates(Festuco-Brometalia) } \\
(* \text { important orchid sites) }\end{array}$ & E1. Dry grasslands & 186,8 \\
\hline $\begin{array}{l}\text { 6230* Species-rich Nardus grasslands, on } \\
\text { siliceous substrates in mountain areas (and } \\
\text { submountain areas, in Continental Europe) }\end{array}$ & $\begin{array}{l}\text { E4. Alpine and subalpine } \\
\text { grasslands }\end{array}$ & 161,7 \\
\hline $\begin{array}{l}\text { 62A0 Eastern sub-mediteranean dry grasslands } \\
\text { (Scorzoneratalia villosae) }\end{array}$ & E1. Dry grasslands & 39,5 \\
\hline 62D0 Oro-Moesian acidophilous grasslands & $\begin{array}{l}\text { E4. Alpine and subalpine } \\
\text { grasslands }\end{array}$ & 647,6 \\
\hline $\begin{array}{l}6430 \text { Hydrophilous tall herb fringe communities } \\
\text { of plains and of the montane to alpine levels }\end{array}$ & $\begin{array}{l}\text { E5. Woodland fringes and } \\
\text { clearings and tall forb stands }\end{array}$ & 2,0 \\
\hline $\begin{array}{l}6510 \text { Lowland hay meadows (Alopecurus pratensis, } \\
\text { Sanguisorba officinalis) }\end{array}$ & E2. Mesic grasslands & 0,9 \\
\hline 6520 Mountain hay meadows & E2. Mesic grasslands & 501,8 \\
\hline $\begin{array}{l}8110 \text { Siliceous scree of the montane to snow } \\
\text { levels (Androsacetalia alpinae and Galeopsetalia }\end{array}$ & H2. Screes & 1,0 \\
\hline
\end{tabular}




\begin{tabular}{|c|c|c|}
\hline ladani) & & \\
\hline $\begin{array}{l}8120 \text { Calcareous and calcshist screes of the } \\
\text { montane to alpine levels (Thlaspietea rotundifolit) }\end{array}$ & H2. Screes & 31,0 \\
\hline $\begin{array}{l}8210 \text { Calcareous rocky slopes with chasmophytic } \\
\text { vegetation }\end{array}$ & $\begin{array}{l}\text { H3. Inland cliffs, rock } \\
\text { pavements and outcrops }\end{array}$ & 265,0 \\
\hline $\begin{array}{l}8220 \text { Siliceous rocky slopes with chasmophytic } \\
\text { vegetation }\end{array}$ & $\begin{array}{l}\text { H3. Inland cliffs, rock } \\
\text { pavements and outcrops }\end{array}$ & 8,0 \\
\hline $\begin{array}{l}8230 \text { Siliceous rock with pioneer vegetation of } \\
\text { the Sedo-Scleranthion or of the Sedo albi- } \\
\text { Veronicion dillenii }\end{array}$ & $\begin{array}{l}\text { H3. Inland cliffs, rock } \\
\text { pavements and outcrops }\end{array}$ & 111,3 \\
\hline 9110 Lu₹ulo-Fagetum beech forests & $\begin{array}{l}\text { G1. Broadleaved deciduous } \\
\text { woodland }\end{array}$ & 7,1 \\
\hline 9130 Asperulo-Fagetum beech forests & $\begin{array}{l}\text { G1. Broadleaved deciduous } \\
\text { woodland }\end{array}$ & 601,6 \\
\hline $\begin{array}{l}9150 \text { Medio-European limestone beech forests } \\
\text { of the Cephalanthero-Fagion }\end{array}$ & $\begin{array}{l}\text { G1. Broadleaved deciduous } \\
\text { woodland }\end{array}$ & 471,5 \\
\hline 9170 Galio-Carpinetum oak-hornbeam forests & $\begin{array}{l}\text { G1. Broadleaved deciduous } \\
\text { woodland }\end{array}$ & 1426,5 \\
\hline $\begin{array}{l}\text { 91E0* Alluvial forests with Alnus glutinosa and } \\
\text { Fraxinus excelsior (Alno-Padion, Alnion incanae, } \\
\text { Salicion albae) }\end{array}$ & $\begin{array}{l}\text { G1. Broadleaved deciduous } \\
\text { woodland }\end{array}$ & 6,3 \\
\hline 91BA Moesian silver fir forests & G3. Coniferous woodland & 417,8 \\
\hline $\begin{array}{l}\text { 91CA Rhodopide and Balkan Range Scots pine } \\
\text { forests }\end{array}$ & G3. Coniferous woodland & 3394,2 \\
\hline 91W0 Moesian beech forests & $\begin{array}{l}\text { G1. Broadleaved deciduous } \\
\text { woodland }\end{array}$ & 65,9 \\
\hline $\begin{array}{l}9270 \text { Hellenic beech forests with Abies borisii- } \\
\text { regis }\end{array}$ & $\begin{array}{l}\text { G1. Broadleaved deciduous } \\
\text { woodland }\end{array}$ & 86,6 \\
\hline $\begin{array}{l}\text { 92D0 Southern riparian galleries and thickets } \\
\text { (Nerio-Tamaricetea and Securinegion tinctoriae) }\end{array}$ & F9. Riverine and fen scrubs & 2,0 \\
\hline $\begin{array}{l}9410 \text { Acidophilous Picea forests of the montane to } \\
\text { alpine levels (Vaccinio-Piceetea) }\end{array}$ & G3. Coniferous woodland & 8471,8 \\
\hline $\begin{array}{l}\text { 9530* (Sub-) Mediterranean pine forests with } \\
\text { endemic black pines }\end{array}$ & G3. Coniferous woodland & 1859,2 \\
\hline
\end{tabular}




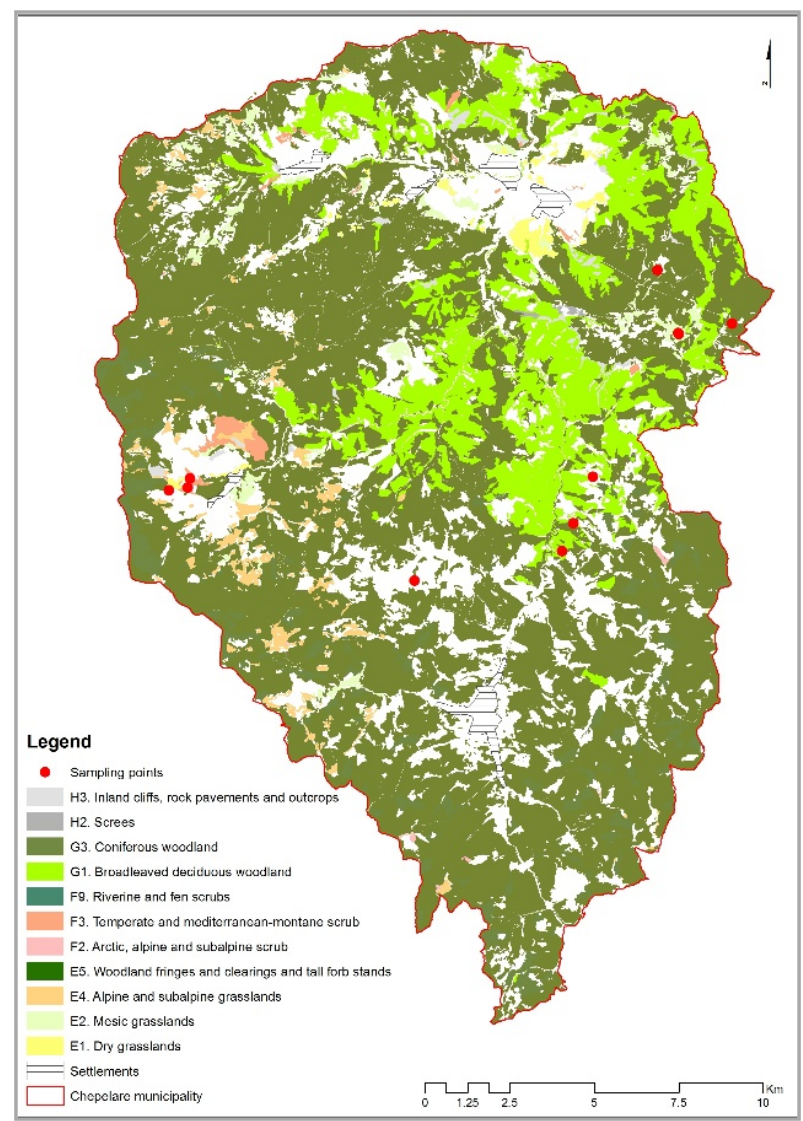

Fig. 2. Map of habitat types in Chepelare Municipality based on EUNIS classification

The plan for the multifunctional forest management in the municipality of Chepelare (2009) states that if the survey results for the two main habitats of blueberry (Vacinim myrtillus) in the forested areas of "Chepelare" and "Hvoina" Forestries is considered relevant to the whole territory it can be inferred that in normal fruitful year the forests dominated by spruce (Picea abies) will yield a full harvest about $150.6 t$ of blueberries. In forests dominated by Scots pine (Pinus sylvestris) the yield is about $15 t$. The free market price of wild strawberries is $10 \mathrm{BGN} / \mathrm{kg}$, raspberries and blueberries in the peak of the summer season are bought out respectively at the price of $2 \mathrm{BGN} / \mathrm{kg}$ and $3 \mathrm{BGN} / \mathrm{kg}$. If the potential amount of blueberries, which can be collected in the municipality is multiplied with the appointed price $(150.6 t$ by $3 \mathrm{BGN})$, the potential sum of 456800 $\mathrm{BGN}$ is the calculated revenue of blueberries from spruce forests only. In the forests of Scots pine the potential revenue is calculated to be $45000 \mathrm{BGN}$ ( $15 t$ by $3 \mathrm{BGN}$ ). The total revenue of $501800 \mathrm{BGN}$ is the amount that may be considered annual value of the provisioning ecosystem service - collection of blueberries in the coniferous forests of the municipality, which is approximately $250900 €$ per year.

If other relevant data referring to the neighboring Batak Municipality is taken into consideration, specifically the analysis of the forest management plans of "Batak", 
"Beglika", "Shiroka polyana", "Rodopi" and "Borovo" Forestries, some other estimations could be made. From the above-mentioned forestries in average $13 t$ of herbs, $17 t$ of berries and $22 t$ of wild mushrooms, $345 t$ of hay and $100 \mathrm{~m}^{3}$ of foliar fodder could be harvested annually. Presented data is based more on expertise than on specific studies. Referencing to the common wood-productive area allows to obtain the following average annual yields per hectare: herbs - $0.236 \mathrm{~kg} / \mathrm{ha}$, berries - $0.310 \mathrm{~kg} / \mathrm{ha}$ and wild mushrooms $-0.400 \mathrm{~kg} / \mathrm{ha}$. These contingent annual average yields per hectare of forest area are indicative of the entire Western Rhodopes and if we apply the transfer method for valuation of ecosystem goods and services, we can calculate that the forests in Chepelare Municipality (19,983 ha) may yield $1113 \mathrm{~kg}$ herbs of different medicinal plants, each of which has a different purchase price. For example, the fresh fruits of blue juniper are bought out at the price of $1.5 \mathrm{BGN} / \mathrm{kg}$, the elderberry blossom - at 2.2 $\mathrm{BGN} / \mathrm{kg}$, the lime blossom reaches $3.5 \mathrm{BGN} / \mathrm{kg}$. Assuming an average price for all herbs of about $2.25 \mathrm{BGN} / \mathrm{kg}$ will allow to calculate that their potential revenue value in the municipality of Chepelare is 5635 BGN per year $(2817,5 €)$. If the purchase price of berries is 5 BGN in average, the forest area of $19983 \mathrm{ba}$ will yield about $6195 \mathrm{~kg}$ and a revenue of 30974 BGN (15 $487 €$ ). This value indicates almost 16 times lower cost than estimated in the forest management plan of Chepelare, which is a matter of expertise. The total yield of mushrooms from the forest area in the municipality is $3197 \mathrm{~kg}$. Considering that the purchase prices of the various mushrooms range from $11 \mathrm{BGN} / \mathrm{kg}$ for edible boletus porcino (Boletus edulis), $20 \mathrm{BGN} / \mathrm{kg}$ for the St. George's mushroom (Calocybe gambosa) and $35 \mathrm{BGN} / \mathrm{kg}$ for the common morel (Morchella esculenta), we can assume that the average purchase price of mushrooms is $20 \mathrm{BGN} / \mathrm{kg}$. By multiplying the average purchase price, average yield and forest area in the municipality the annual value of the provisioning ecosystem goods - wild mushrooms, could be estimated at the amount of 63946 BGN (31 $973 €)$.

The conducted questionnaire survey among municipal residents (Assenov and Borissova, 2016), combining the contingent valuation method and the method of market prices, involved 38 respondents (25 were interviewed in the municipal center and 13 in two of the villages). The obtained data for the purpose of the study refer to the amount of berries, herbs and mushrooms collected by residents in BGN. The calculated average values are as follows: wild mushrooms for own consumption - 81,67 BGN in the town of Chepelare and 83,33 BGN in the villages; wild mushrooms for buyout - $200 \mathrm{BGN}$ in the town of Chepelare and 168,75 BGN in the villages; herbs and berries for own consumption - 67,63 BGN in the town of Chepelare and 62,50 BGN in the villages; herbs and berries for buyout - $75 \mathrm{BGN}$ in the municipal center and $80 \mathrm{BGN}$ in the villages of the municipalities. The limited number of respondents does not allow considering those average values as representative for the municipality and for that reason they are not used for further estimations but they provide general idea of the value of ecosystem goods provided by nature and utilized by locals.

\section{Conclusions}

The fulfilled study aiming to quantify the potential genetic biodiversity in the form of herbs, berries and mushrooms on the basis of existing biotopes, habitat diversity 
and landscape biodiversity provided reliable results based on the implemented monetary valuation of ecosystems/landscape goods, for which no quantitative database in Bulgaria is currently existing. The floristic genetic biodiversity of the particular municipality is exhaustively discussed, while the faunistic genetic biodiversity is not considered due to the limited size of the paper. Some conclusions can be made that will support further study of ecosystem/landscape goods and services in the municipality:

- It may be assumed that the identified average values of herbs, berries and mushrooms harvested as provisioning ecosystem/landscape goods are close to their real values;

- The number of respondents to the conducted questionnaire survey is not sufficient to obtain representative results which imposes expanding of the survey by increasing the sample;

- The lack of quantitative data for the interpreted provisioning ecosystems/landscape goods implies the development of a new questionnaire form to obtain more detailed information;

- The integration of ecosystem information in an innovative database for the provisioning products from nature is regarded as a prospect for the sustainable development of mountain communities and as a possibility to preserve biodiversity;

- The valuation of ecosystem/landscape services implemented in Chepelare Municipality is a precondition for modeling of landscape planning in the municipality.

\section{Acknowledgements}

This research is sponsored by the "National, European, and Civilizational Dimensions of the Culture - Language - Media Dialogue" Program of the "Alma Mater" University Complex in the Humanities at Sofia University "St. Kl. Ohridski", funded by the Bulgarian Ministry of Education and Science - Bulgarian Science Fund.

\section{References}

Assenov, A., B. Borissova. 2016. Value of Ecosystems (Landscape) Services in the Area of the Towns of Apriltsi, Kalofer and Smolyan. Annuaire de L'Universite de Sofia "St. Kliment Ohridski", Faculte de Geologie et Geographie, Livre 2 - Geographie, Tome 107. 141-163 pp.

Assyov, B., A. Petrova, D. Dimitrov, R. Vassilev. 2012. Conspectus of the Bulgarian Vascular Flora. Bulgarian Biodiversity Foundation, Sofia, p. 489.

Borossova, B., A. Assenov. 2016. Importance of hemeroby indicator index in landscape assessment and monitoring of mountain regions (the example of Smolyan). Annuaire de l'Universite de Sofia "St. Kl. Ohridski”, Faculte de Geologie et Geographie, Livre 2 - Geographie, Tome 108.

CORINE 1990-2012, http://eea.government.bg/bg/projects/korine-14/index

Council Directive 2009/147 EC and the older version 79/409 CEE. 1979

Council Directive 92/43 EEC. 1992.

Davies C.E., D. Moss. 1997. EUNIS habitat classification: final report. European Environment Agency, European topic centre on nature conservation, 1997 work programme: task 7.5.1. 164 p.

Davies C.E., D. Moss, M. O'Hill. 2004. EUNIS habitat classification. Revision 2004. [EEA] European Environment Agency.

Denchev, C., M. Gyosheva, B. Rosnev. 2005. Fungal diversity of Bulgaria - current state of research, preservation and rational use. In: "Current state of Bulgarian biodiversity - problems and perspectives", reports presented at the national meeting devoted to the International Day for Biological Diversity - 22 May 2004, Sofia, 3-4 May 2004. Studio Dragon, pp. 37-67 (in Bulgarian). 
Denchev, C., M. Gyosheva, G.Bakalova, V. Fakirova, R. Petrova, E. Dimitrova, E. Sameva, D. Stoykov, B. Assyov, S. Nikolova. 2006. Fungal diversity of the Rhodopes (Bulgaria). - In: Beron, P., (ed). Biodiversity of Bulgaria. 3. Western Rhodopes (Bulgaria and Greece) I. 81-131. Pensoft \& Nat. Mus. Natur. Hist., Sofia.

EEA, 2015, The European environment - state and outlook 2015: synthesis report, European Environment Agency, Copenhagen.

Ganeva, A., 2006. Bryophyte diversity in the Rodopes Mts. (Bulgaria). - In: Beron, P., (ed). Biodiversity of Bulgaria. 3. Western Rhodopes (Bulgaria and Greece) I. Pensoft \& Natr. Mus. Natur. Hist., Sofia. 177-190.

Mapping and evaluation of ecosystems and their services. 2013. An analytical framework for ecosystem assessments under Action 5 of the EU Biodiversity Strategy to 2020. Discussion Paper, European Union.

McGarigal, K., S.A. Cushman, E. Ene. 2012. FRAGSTATS v4: Spatial Pattern Analysis Program for Categorical and Continuous Maps. Computer software program produced by the authors at the University of Massachusetts Amherst. http://www.umass.edu/landeco/research/fragstats/fragstats.html.

Mücher et al., (2010) C. Mücher, J. Klijn, D. Wascher, J. Schaminee. A new European Landscape Classification (LANMAP): A transparent, flexible and user-oriented methodology to distinguish landscapes, Ecological Indicators, 10:87-103.

Municipal development plan of Chepelare Municpality $2014-2020$ (in Bulgarian) file:///D:/studenti/RRP/obschinskiplanzarazvitienaobschinachepelare.pdf

NATURA 2000 http:// natura2000.moew.government.bg/

Plan for the multifunctional forest management in the municipality of Chepelare. 2009. http:// chepelare.org/?page=pages\&id=1389

Report on the extent of impact of the Master plan (phase: preliminary report) of Chepelare Municipality on the subject and objectives of the protected areas. 2016. Povvik Ltd., Consultants and engineers on environment and sustainable development.

Temniskova, D., I. Kirjakov. 2006. Biodiversity of algae in the Rhodopes (Bulgaria). - In: Beron, P., (ed). Biodiversity of Bulgaria. 3. Western Rhodopes (Bulgaria and Greece). Pensoft \& Nat. Mus. Natur. Hist., Sofia. 133-176.

Temniskova, B., I. Kirjakov, S. Moncheva, M. Stoyneva, R. Mladenov, D. Belkinova, R. Stancheva, P. Ivanov. 2005. Biodiversity of algae in Bulgaria. In: "Current state of Bulgarian biodiversity problems and perspectives", reports presented at the national meeting devoted to the International Day for Biological Diversity - 22 May 2004, Sofia, 3-4 May 2004. Studio Dragon, pp. 11-36 (in Bulgarian).

Toplyiski, D. 1998. Chronological structure of the humidity index of Thornthwaite in Bulgaria. In: Papers from the International Scientific Conference - 100 Anniversary of Geography at Sofia University, "St. Kliment Ohridski" University Press. 31-38 pp. (in Bulgarian).

Velev. S. 2010. Climate of Bulgaria. Heron Press, Sofia, p.189 (in Bulgarian)

Vihervaara P, Kumpula T, Tanskanen A, Burkhard B. 2010. Ecosystem services - a tool for sustainable management of human-environment systems. Case study Finnish Forest Lapland. Ecol Compl. 7(3):410-420.

Vihervaara P., T. Kumpula, A. Ruokolainen, A. Tanskanen \& B. Burkhard, 2012. The use of detailed biotope data for linking biodiversity with ecosystem services in Finland, International Journal of Biodiversity Science, Ecosystem Services \& Management, 8:1-2, 169-185. http://dx.doi.org/10.1080/21513732.2012.686120

Vincent, Jeffrey R.. 2012. Ecosystem services and green growth. Policy Research working paper; no. WPS 6233. Washington, DC: World Bank. http://documents.worldbank.org/curated/en/2012/10/16835826/ecosystem-services-greengrowth 